\title{
The Effects of Social Media Marketing Antecedents on Social Media Marketing, Brand Loyalty and Purchase Intention: A Customer Perspective
}

\author{
Bader M. A. Almohaimmeed \\ Business Administration Department, College of Business and Economics (CBE) \\ Qassim University, Buraydah, Saudi Arabia
}

\section{Keywords}

Social media antecedents, social media marketing, brand loyalty and purchase intention

\begin{abstract}
The aim of this study was to explore the effects of the antecedents of social media marketing, brand loyalty and purchase intention. Furthermore, the study aims at investigating the effect of social media marketing on brand loyalty and purchase intention. Finally, the study seeks to identify the effect of brand loyalty on purchase intention. In order to achieve the study objectives, a questionnaire was developed based on prior literature and a sample of customers consisting of 500 participants was selected in order to collect the required data. The model of the study was developed theoretically and then tested using structural equation modeling.

The results confirmed that social media antecedents significantly affect three constructs: social media marketing, brand loyalty and customer purchase intention. In line with numerous previous studies, the results indicated that social media marketing significantly affects both brand loyalty and customer purchase intention. Finally, the findings showed that brand loyalty has a significant effect on customer purchase intention. Based on these results, it was concluded that organizations should pay more attention to the antecedents of social media marketing since it has direct effects on social media marketing application, brand loyalty and customer purchase intention. Despite the importance of these results, the study is still limited to measurements used to evaluate constructs, since these measurements were built on a small number of indicators, its cross-sectional design and a little number of antecedents being explored. Considering these limitations in the future might reveal different results. However, since the effect degree of social media marketing application is greater than the degree of the same construct on brand loyalty and purchase intention, social marketing application was not approved to play a mediating role between theses constructs. Hence, the major contribution of this study is that social media antecedents are no less important than the application of social media marketing itself. In other words, for organizations to ensure an effective application of social media marketing, an eye on its antecedents would bring the benefits of social media marketing into the light, which, in turn, would affect brand loyalty and customer purchase intention.
\end{abstract}

Corresponding author: Bader Almohaimmeed

Email addresses of the corresponding author:bmam@qu.edu.sa

First submission received: 16th September 2018

Revised submission received: 1st December 2018

Accepted: 28th December 2018

\section{Introduction}

A new tool of communication was introduced in the early 2000s, which became widely known as social media. The main feature of this tool is interaction among users (Singh \& RatnaSinha, 2017). Therefore, it is regarded as a tool that has the greatest influence on organizations communication with customers and the public (Parveen, 2012). In fact, one of the most important drivers for organizations to utilize social media is the large number of people who use social media applications such as Facebook (Sharif, Troshani, \& Davidson, 2015). According to Zahoor and Qureshi (2017), social media refers to web technologies utilized for interaction with public communities. Tuten and Solomon (2015) stated that a new “" $\mathrm{p}$ " was emerging and added to the marketing mix Ps' with the introduction of social media to become the five Ps, which are product, price, promotion, place, participation or social media marketing. They 
defined the fifth ' $\mathrm{P}$ ' as an application of social media technologies to build an environment in which the intended value is created to fulfill stakeholders' requirements. Since organizations seek to build brand loyalty, one of the means that can be utilized to achieve this goal was social media (Erdogmus \& Cicek, 2012) due to its benefits over traditional marketing means. Examples of these benefits include increased levels of organizational performance (Alarcón, Rialp, \& Rialp, 2015), brand loyalty (Tatar \& ErenErdoğmuş, 2016), user consumption patterns (Thoene, 2012) and purchasing behaviors of consumers (Hayta, 2013). Consequently, the positive effect of social media marketing on constructs such as brand loyalty and purchase intention were well reported in the literature. However, relationships between the antecedents of social media marketing, social media marketing, brand loyalty and customer purchase intention had not gained great attention from researchers to be studied in the same model in local organizations. Therefore, the aim of this study is to explore effects among the antecedents of social media marketing, social media marketing, brand loyalty and customer purchase intention in order to understand the real effect of these factors when tested simultaneously in one model. The study is organized into seven sections. The following section sheds light on social media marketing. Section three shows the development of study hypotheses and model. Section four displays the methodology used in the study. Data analysis and results are illustrated in section five, followed by discussion and conclusion in section six. Finally, implications, limitations and recommendations for future research are clarified in section seven.

\section{Social Media Marketing}

Definitions of social media found in the literature, in general, are grounded on two crucial pillars: the Internet and public interaction. Zahoor and Qureshi (2017) defined social media as web technologies utilized to interact with public communities. Interest in social media in the marketing domain has gained increased attention due to the potential effect of these technologies on customer behavior. Additionally, organizations' interest in social media is derived by numerous benefits organizations can achieve such as reducing cost, increasing profitability, sharing knowledge and building business partnerships (Neti, 2011). Hence, researchers have studied social media and social media marketing in different domains such as the impact of social media on customers (Hajli, 2013); effects of social media marketing on online consumer behavior (Vinerean, Cetina, \& Tichindelean, 2013); the effect of social media marketing on online shopping (Mohammadpour, Roshandel Arbatani, Hassan Holipour, Farzianpour, \& Hosseini, 2014), social media strategies (Bajpai, Pandey and Shriwas, 2012); creative strategies in social media marketing (Ashley \& Tuten, 2015); impact of social media marketing on brand loyalty and purchase intention (Balakrishnan, Dahnil, \& Yi, 2014); antecedents of social media marketing application (Brech, Messer, Schee, Rauschnabel, \& Ivens , 2017); foundations of social media marketing (Constantinides, 2014); effectiveness of social media such as Facebook advertising in enhancing purchase intention (Dehghani \& Tumer, 2015); impact of social media marketing on brand loyalty (Erdogmus \& Cicek, 2012); antecedents of social media analysis (Guede, Curiel, \& Antonovica, 2017); the impact of user interactions in social media on brand awareness and purchase intention (Hutter, Hautz, Dennhardt, \& Füller, 2013); corporate reputation and customer behavioral intentions (Keh \& Xie, 2008) social media marketing and brand equity (Zahoor \& Qureshi, 2017).

\section{Hypotheses and Study Model Development Antecedents of SMM and SMM}

Recent research on social media marketing (SMM) designated several factors that have vital influences on SMM. In one study on the interaction between universities and fans, Brech et al. (2017) marked out two of these factors: university reputation and frequency of updates. Leung, Bai and Mehmet Erdem (2017) made a reference to the content type of social media. Their study was on the social media marketing of hotels, i.e., Facebook, and found that the most effective types of messages were those related to product, brand and involvement but not those related to reward and promotions. Product involvement and attitude towards the community and interest in online interaction are identified by Dessaert (2017) as these factors have an impact on social media engagement. Moreover, Odoom, Anning-Dorson and Acheampong (2017) distinguished two types of social media motivations: product-based and serviceoriented. Brink (2017) described open, collaborative business model and distributed leadership as the two 
antecedents of SSM. Furthermore, word of mouth communication done using electronic means to promote products or services is called viral marketing via social media (Guede et al., 2017). On the basis of these findings, the first hypothesis of this study was formulated in order to explore the effect of ten social media antecedents on strategic social media marketing:

H1: SMM antecedents significantly affect SMM.

Table 1. Examples of SMM Antecedents Found in the Literature

\begin{tabular}{lll}
\hline No. & SMM antecedents & Authors \\
\hline 1 & Organization reputation & Brech et al. (2017) \\
2 & Frequency of social media updates & Leung et al. (2017) \\
\hline 3 & SMM content type & \\
\hline 4 & Product involvement & Dessaert (2017) \\
5 & Attitude towards community & \\
6 & Interest in online interaction & Odoom et al. (2017) \\
\hline 7 & Social media motivations & Brink (2017) \\
8 & Open collaborative business model & Guede et al. (2017) \\
\hline 10 & Distributed leadership & Brand communication via viral marketing
\end{tabular}

\section{SMM and Brand Loyalty}

Ismail (2017) studied the influence of SMM activities on brand loyalty and found that the former has a significant impact on the latter. Erdogmus and Cicek (2012) found a significant impact of social media marketing on brand loyalty, particularly when a brand encompasses popular as well as relevant content publicized on different platforms. Balakrishnan et al. (2014) found a positive impact of SMM on brand loyalty. Rialti, Zollo, Pellegrinie and Ciappei (2017) indicated that the brand loyalty of customers is influenced by their engagement in the social media brand community and brand trust. Bruhn, Schoenmueller and Schäfer (2012) compared the effects of traditional communication media and social media communication on brand awareness and image. Their results showed that a significant impact of traditional media was on brand awareness while a significant impact on social media was on brand image. According to Schultz (2017), brand posts as one of the post characteristics is considered a key advantage of social networks as well as has a positive impact on customer social interaction. Munnukka, Karjaluoto Mahlamäki and Hokkanen (2017) argued that social media engagement has a positive influence on the customer brand experience, which, in turn, affects their brand loyalty. Parganas, Anagnostopoulos and Chadwick (2017) reported similar positive perceptions of the brand among customers as a result of using social networks such as Facebook. Consequently, it was assumed in the second hypothesis of this study that:

H2: SMM significantly affects brand loyalty.

\section{SMM and Purchase Intention}

Balakrishnan et al. (2014) investigated the impact of SMM on brand loyalty and purchase intention and indicated that SSM, particularly electronic word of mouth, online communities and online advertisements, has positive effects on brand loyalty and purchase intention. Gautam and Sharma (2017) emphasized that SMM and customer relationships significantly and positively affect customers' purchase intention. Yadav and Rahman (2017) revealed that SMM activities positively affected customer purchase intention as well as brand equity. Sheth and Kim (2017) highlighted that SMM has a significant influence on customer purchase intention. Hutter et al. (2013) demonstrated that SMM using Facebook resulted in positive influences on brand awareness, word of mouth and customer purchase intention. Moreover, investigating the role of Facebook, Dehghani and Tumer (2015) showed that Facebook advertising has significant impacts on both brand image and equity, which, in turn, have a significant impact on customers' purchase intention. According to $\mathrm{Ng}$ (2013), a social network community has a significant influence and customer purchase intention is mediated by trust. These results stimulated the hypothesis that:

H3: SMM significantly affects customer purchase intention. 
Figure 1 shows a model comprising three hypotheses derived based on the literature reviewed in sections 3.1, 3.2 and 3.3. These hypotheses assumed the effects of social media marketing antecedents organization's reputation, frequency of social media updates, SMM content type, social media motivations, and open collaborative business model on social media marketing and suggested the effects of SMM on both brand loyalty and customer purchase intention.

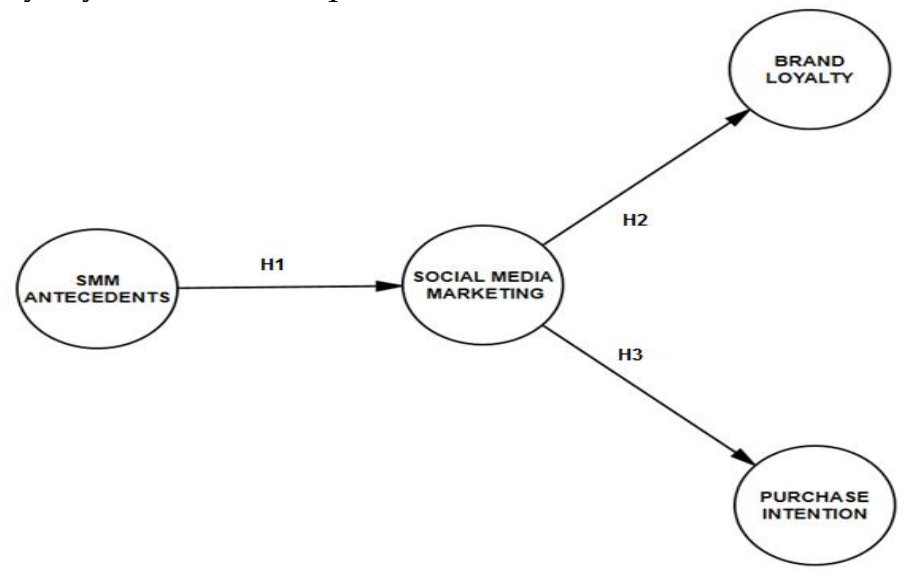

\section{SMM Antecedents and Brand Loyalty}

Figure 1. Hypotheses 1-3

SMM antecedents used in this study are: an organization's reputation, frequency of social media updates, SMM content type, social media motivations and brand communications. In general, there is a positive relationship between the reputation of the organization and customer loyalty (Gul, 2014). Liengjindathaworn, Saenchaiyathon and Hawat (2014) found a significant effect of corporate reputation from customers' perceptions on brand loyalty. The results of Caruana and Ewing (2010) suggested a positive effect of corporate reputation on online loyalty. Seo and Park (2017) showed a significant impact of corporate reputation on brand image and brand preference and the latter has a significant impact on brand loyalty. In a meta-analysis study aimed at exploring the antecedents and mediators of brand loyalty conducted by $\mathrm{Wu}$ and Anridho (2016), corporate reputation was a significant predictor of brand loyalty. In relation to the frequency of updates, Brech et al. (2017) emphasized the importance of frequent social media updates to ensure customer engagement. According to them, a balanced level of update frequency ensures a good level of customer engagement in social media. Laroche, Habibi and Richard (2013) indicated that customer engagement in social media has an appositive effect on brand trust, which, in turn, has a positive influence on brand loyalty. Secondly, the valuable content of social media was found by Jahn and Kunz (2012) to be a main driver of user engagement. Their results showed that using social media has a positive impact on brand loyalty. Thirdly, Wonly and Mueller (2013) indicated that relevant social media motivations such as brand commitment and involvement motivate users to engage in brand interactions. Finally, Chinomona (2016) indicated that brand communication has a significant impact on brand loyalty in the presence of brand image as a mediating variable in the relationship between brand communication and brand loyalty. In fact, these findings induced that:

H4: SMM antecedents significantly affect brand loyalty.

Figure 2 exhibits a new hypothesis (H4) added to those illustrated in Figure 1. The hypothesis assumed a positive effect of social media antecedents (corporate reputation, social media frequency updates, content of social media, social media's motivations and brand communication) on brand loyalty. 


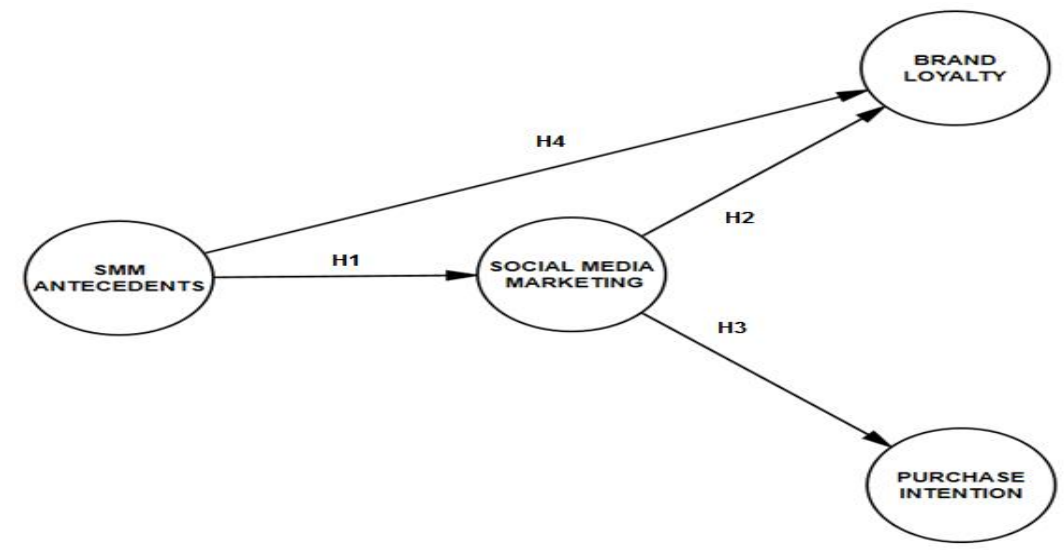

Figure 2. Hypotheses 1-4

\section{SMM Antecedents and Customer Purchase Intention}

Corporate reputation as one of the antecedents used in this study has a significant relationship with behavioral intentions of customers with a mediating role played by customer commitment (Keh \& Xie, 2008). Lafferty, Goldsmith and Newell (2002) showed that corporate credibility has a significant impact on purchase intention. According to Oztamur and Karakadilar (2014), the frequency of social media updates is positively related to customer engagement in social interactions. Furthermore, electronic word of mouth in social interactions has an impact on purchase intention (See-To \& Ho, 2014). With respect to the content type of social media, Hutter et al. (2013) found a non-significant impact of customer annoyance with social media content and purchase intention. Muntinga, Moorman and Smit (2011) indicated that knowing the motivations of customers to use social media can be utilized in order to direct their behaviors, particularly their purchase intention. Finally, Schivinski and Dąbrowski (2013) showed that brand communication has a non-significant influence on customer purchase intention. Based on these results, it was suggested that: H5: SMM antecedents significantly affect purchase intention.

Figure 3 displays a new hypothesis added to those illustrated in Figure 2. The hypothesis presumed that social media antecedents are significantly related to customer purchase intention.

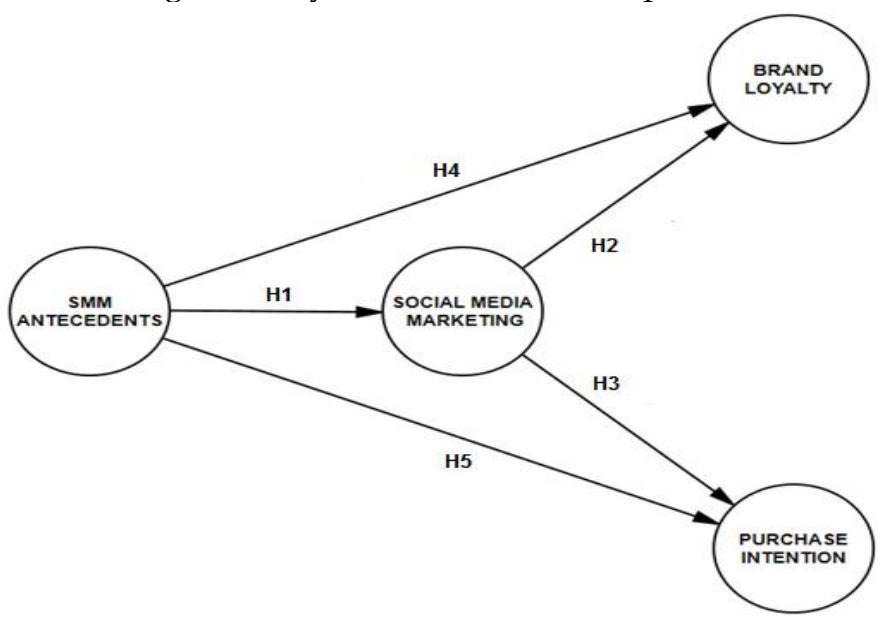

Figure 3. Hypotheses 1-5

\section{Brand Loyalty and Customer Purchase Intention}

In a study conducted by Pandey and Srivastava (2016) on the antecedents of customer purchase intention, customer loyalty to a brand was found to be one of the most important drivers of customer purchase intention. Moreover, Chi, Yeh and Yang (2009) found a positive impact of brand loyalty on customer purchase intention. The same finding was echoed in many studies (Calvo-Porral, MartínezFernández, Juanatey-Boga, \& Lévy-Mangín, 2015; Chen, Chen, \& Lin, 2016; Malik, Ghafoor, \& Iqbal, 2013; Shahid, Hussain, \& aZafar, 2017). Consequently, the following hypothesis was added: H6: Brand loyalty significantly affects purchase intention. 
Figure 4 demonstrates the final model developed in this study, in which a new hypothesis was added (H6) to the previous model portrayed in Figure 3. This consists of six hypotheses: Hypothesis 1 clarifies the effect of SMM antecedents on SMM, Hypothesis 2 postulates that SMM significantly affects brand loyalty, Hypothesis 3 suggests that SMM has a significant effect on purchase intention, Hypothesis 4 presumes that SMM antecedents significantly affect brand loyalty, and Hypothesis 5, on the other hand, assumes that SMM antecedents have a significant effect on purchase intention. Finally, there is a significant effect, according to hypothesis 6 , of brand loyalty on purchase intention.

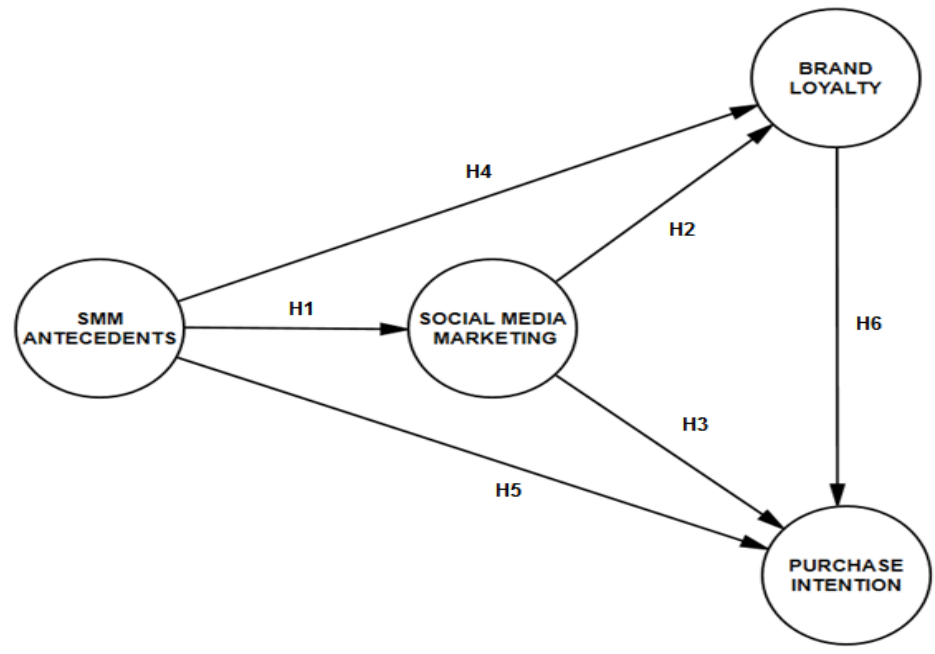

\section{Study Methodology \\ Study Sample}

Figure 4. Study model

A questionnaire was developed and distributed to 500 randomly selected customers from those who visited small appliance shops in three malls of Riyadh. Only 377 questionnaires were returned complete and usable for analysis. The sample size used in this study is considered acceptable based on rules of thumb provided by VanVoorhis and Morgan (2007) since the sample comprised no less than 300 participants.

\section{Measurements}

The SMM antecedents used in this study were corporate reputation, social media frequency updates, content of social media, social media motivations and brand communications. Corporate reputation was measured using two items: 'this organization is reputable' adopted from Byrum (2017) and 'this organization is committed to the society' adopted from Calvo-Porral et al. (2015). In addition, social media frequency updates were measured based on updates, relevance, not too infrequent and not too frequent updates (Brech et al., 2017). The content of social media was evaluated based on the study by Guede et al. (2017) and Leung et al. (2017) using two dimensions related to content understandability and content format such as pictures and colors. Social media motivations were measured by two items related to personal identity and social interaction (Muntinga et al., 2011). Brand communication via viral marketing was assessed based on Guede et al. (2017) by two items 'promoting brand message' and 'cocreation of customer value'. Using three dimensions adopted from Constantinides (2014), social media marketing was measured by application types, social effects and enabling technologies. Furthermore, brand loyalty was measured using three items adopted from Ha, John, Janda and Muthaly (2011) and related to positive word of mouth, continuity of using the same brand regardless of its price and deciding to buy the same brand in case it is available. Finally, two items were adopted from Balakrishnan et al. (2014) to evaluate customer purchase intention (buying intention in the future and repurchase decision).

\section{Data Analysis and Results \\ Reliability and Validity}

The application of Structural Equation Modeling (SEM) was done on the basis of Hair, Black, Babin and Anderson (2010). Subsequently, Cronbach's coefficient alpha was used to test the reliability of internal consistency with values no lower than 0.70 along with the Kaiser-Meyer-Olkin (KMO) test with a 
recommended value greater than 0.70 . Construct validity was evaluated based on convergent and discriminant validity. Therefore, factor loadings were $\geq 0.50$, composite reliability was at least 0.60 and the average variance extracted (AVE) was at least 0.50 . This study applies a full application of structural equation modeling, that is, a measurement model is used to explore relationships between indicators used to measure constructs, in addition to a structural model to investigate the directional relationships between constructs (Hoyle, 2000). Glynn and Woodside (2009) indicated that three important measurements should be considered in structural equation modeling: absolute fit, incremental fit and parsimonious fit. The first one can be used to investigate the ability of the overall model, which consists of both the measurement and the structural models, to predict the observed covariance. Moreover, Hoyle (2000) argued that the statistical testing involved in confirmatory factor analysis contains two levels: the overall fit and parameter estimates. In addition to Chi-square/degree of freedom, two absolute fit measures, Goodness of Fit Index (GFI) and Root Mean Square Error of Approx. (RMSEA), were used to investigate the overall fit (Calvo-Porral et al., 2015; Al-Tit, 2016). According to Glynn and Woodside (2009), the scale of GFI ranges from 0 to 1 where 0 represents a non-fit model and 1 represents a perfect model fit. The results in Table 2 show that factor loadings for antecedents of SMM were greater than 0.50, $\mathrm{KMO}$ values were greater than 0.70, AVEs were greater than 0.50 and Cronbach's alpha coefficients were greater than 0.70 .

Table 2. Results of Reliability and Validity

\begin{tabular}{|c|c|c|c|c|c|c|}
\hline Construct & Dimensions & Indicators & Loadings & $\mathrm{KMO}$ & AVE & $a$ \\
\hline $\begin{array}{l}\text { Antecedents of } \\
\text { SMM }\end{array}$ & $\begin{array}{l}\text { Corporate reputation } \\
\text { Social media frequency } \\
\text { updates } \\
\text { Content of social media } \\
\text { Social media motivations } \\
\text { Brand communications }\end{array}$ & $\begin{array}{l}\text { ANT1 } \\
\text { ANT2 } \\
\text { ANT3 } \\
\text { ANT4 } \\
\text { ANT5 }\end{array}$ & $\begin{array}{l}0.711 \\
0.689 \\
0.699 \\
0.770 \\
0.821\end{array}$ & 0.736 & 0.648 & 0.74 \\
\hline SMM & $\begin{array}{l}\text { Application types } \\
\text { Social effects } \\
\text { Enabling technologies }\end{array}$ & $\begin{array}{l}\text { SMM1 } \\
\text { SMM2 } \\
\text { SMM3 }\end{array}$ & $\begin{array}{l}0.791 \\
0.674 \\
0.718\end{array}$ & 0.720 & 0.748 & 0.75 \\
\hline Brand loyalty & $\begin{array}{l}\text { Positive word of mouth } \\
\text { Continuity of using the same } \\
\text { brand }\end{array}$ & $\begin{array}{l}\text { BL1 } \\
\text { BL2 }\end{array}$ & $\begin{array}{l}0.881 \\
0.785\end{array}$ & 0.841 & 0.669 & 0.81 \\
\hline $\begin{array}{l}\text { Purchase } \\
\text { intention }\end{array}$ & $\begin{array}{l}\text { Buying intention in the future } \\
\text { Repurchase decision }\end{array}$ & $\begin{array}{l}\text { PI1 } \\
\text { PI2 }\end{array}$ & $\begin{array}{l}0.812 \\
0.796\end{array}$ & 0.708 & 0.685 & 0.84 \\
\hline
\end{tabular}

\section{Model Goodness of Fit Indexes}

Table 3 shows that all goodness of fit indexes used met the recommended rules of thumb. According to Huang, Yen and Zhang (2008), a model is regarded as acceptable in terms of the goodness of fit. In this case, the Chi-square/degree of freedom $\left(x^{2} / \mathrm{df}\right)$ is less than 3, GFI is greater than 0.90 and RMSEA is less than 0.05 .

Table 3. Results of Model Goodness of Fit Indexes

\begin{tabular}{llll}
\hline Index & Criterion & Study model & Result \\
\hline Chi-square/degree of freedom & $<2.00$ & 1.77 & Good \\
Goodness of Fit Index (GFI) & $>0.90$ & 0.97 & Good \\
Root Mean Square Error of Approx. (RMSEA) & $<0.05$ & 0.031 & Good \\
\hline
\end{tabular}

\section{Results of Hypotheses Testing}

The results of path analysis shown in Figure 5 indicate that all hypothesized effects in the study's hypotheses were accepted. There is a statistically significant effect of SMM antecedents on social media marketing $(B=0.27, \mathrm{t}=3.56, \mathrm{P}=0.000)$. Additionally, Hypothesis 2 was accepted since social media marketing has a significant effect on brand loyalty $(\beta=0.46, t=2.93, P=0.000)$. Moreover, social media marketing was found to have a statistically significant effect on customer purchase intention $(B=0.30, t=$ 2.67, $\mathrm{P}=0.000)$, which means acceptance of Hypothesis 3. Moreover, the results show that SMM 
antecedents significantly affect brand loyalty $(\Omega=0.18, t=3.81, P=0.000)$, thereby supporting Hypothesis 4. Furthermore, SMM antecedents significantly affect customer purchase intention $(B=0.28, t=1.97, P=$ 0.000), resulting in Hypothesis 5 being accepted. Finally, brand loyalty has a significant effect on customer purchase intention $(\beta=0.49, \mathrm{t}=4.01, \mathrm{P}=0.000)$.

\section{Discussion and Conclusion}

The six hypotheses proposed in this study were supported. Hypotheses 1, 4 and 5 suggested that social media antecedents as a construct measured using five indicators has a significant effect on social media marketing, brand loyalty and customer purchase intention. Hypotheses 2 and 3 postulated that social media marketing has significant effects on both brand loyalty and customer purchase intention. Hypothesis 6 assumed that brand loyalty has a significant effect on customer purchase intention. Furthermore, concerning the effect of SMM antecedents on social media marketing found in this study, there were similar results that had been revealed in previous studies. Brech et al. (2017) indicated that an organization's reputation and frequency of social media updates as two indicators of social media antecedents positively influence social media marketing. The positive effect of the content type of social media on social media marketing was reported by Leung et al. (2017). Moreover, social media motivations such as product or service-based motivations as well as brand communications have significant impacts on social media marketing (Guede et al., 2017; Odoom et al., 2017). In line with Erdogmus and Cicek (2012), Bruhn et al. (2012), Ismail (2017), Balakrishnan et al. (2014), Rialti et al. (2017), Schultz (2017), Munnukka et al. (2017) and Parganas et al. (2017), the results confirmed that social media marketing has a strong effect on brand loyalty. On the other hand, social media marketing has a significant impact on purchase intention as revealed in numerous prior studies (Balakrishnan et al., 2014; Dehghani \& Tumer, 2015; Gautam \& Sharma, 2017; Hutter et al., 2013; Sheth \& Kim, 2017; Yadav \& Rahman, 2017). In agreement with Gul (2014), Liengjindathaworn et al. (2014), Caruana and Ewing (2010), Seo and Park (2017), Wu and Anridho (2016), Brech et al. (2017), Jahn and Kunz (2012), Wonly and Mueller (2013) and Chinomona (2016), it was found that social media antecedents significantly affect brand loyalty.

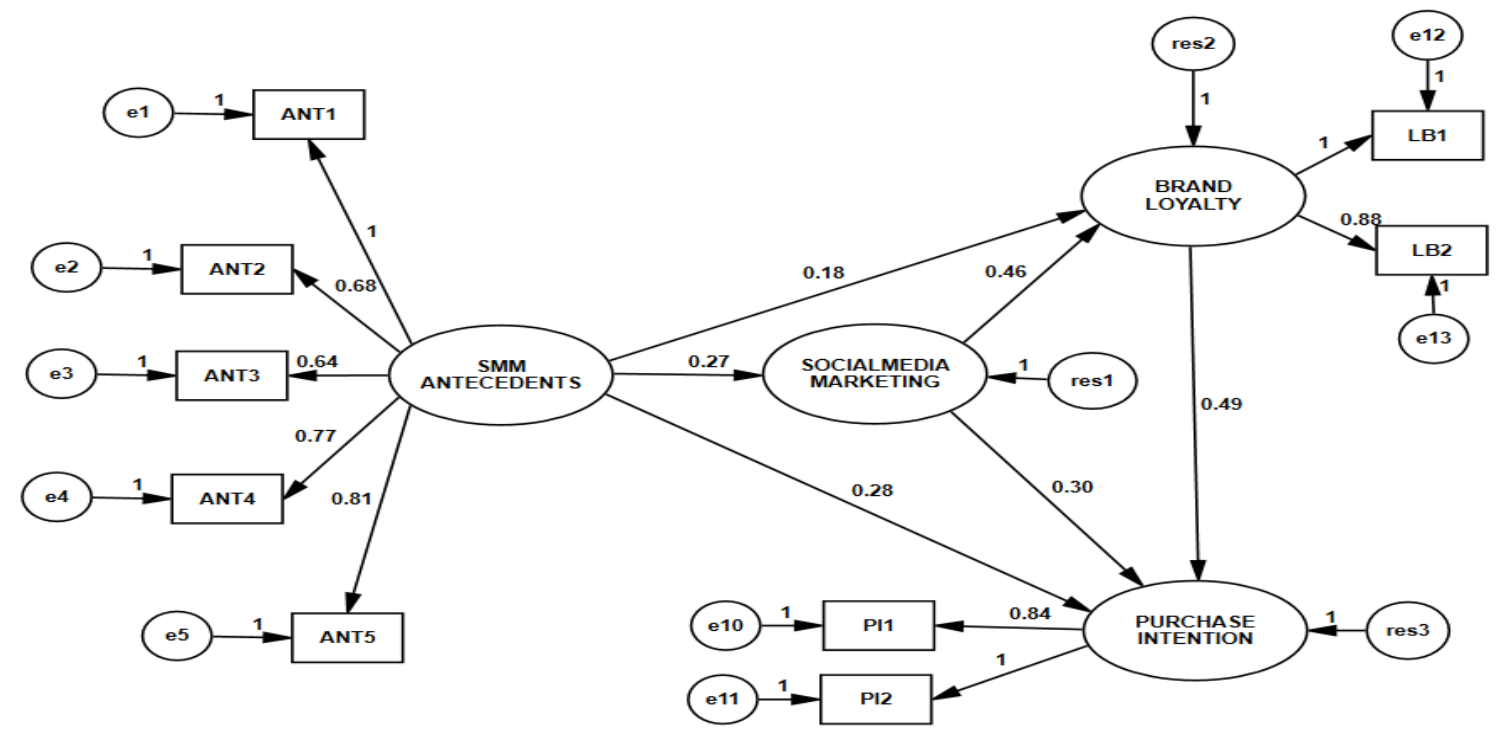

Figure 5. Results of hypotheses testing

The results indicated that social media antecedents have a significant effect on purchase intention. The same result was figured out by Keh and Xie (2008), Lafferty et al. (2002), Oztamur and Karakadilar (2014), See-To and Ho (2014) and Muntinga et al. (2011). Finally, the results showed that brand loyalty significantly affected customer purchase intention (Calvo-Porral et al., 2015; Chen et al., 2016; Chi et al., 2009; Pandey \& Srivastava, 2016; Malik et al., 2013; Al-Tit \& Nakhleh; Shahid et al., 2017). For organizations to start an effective application, five antecedents should be considered: corporate reputation, social media frequency updates, content of social media, social media motivations and brand communications. Corporate reputation has increased customer engagement in using social media marketing since reputation results in trust. Ashley and Tuten (2015) highlighted the importance of social media content 
and frequent updates. They argued that such content should be fresh, frequently updated and involve incentives that encourage customer engagement. Additionally, a prior step of social media marketing for organizations is to include product and service-based motivations using brand communication means (Brink, 2017; Odoom et al., 2017). Due to the effective role played by social media marketing, it was found to mediate the relationship between social media antecedents and brand loyalty. Moreover, brand loyalty has been defined as an attachment between the customer and the brand (Balakrishnan et al., 2014). The effect of brand loyalty on purchase intention can be explained through levels of brand loyalty itself: behavioral and cognitive loyalty. The first is related to customer behavior and can be described or measured in terms of customer repeated purchase or customer commitment to re-buy the same brand. On the other hand, cognitive loyalty refers to the customers' first preference of the brand (Balakrishnan et al., 2014). An ultimate logical result of brand loyalty is to increase customer purchase intention.

\section{Implications, Limitations and Future Research}

Loyal customers who have their own behavior or cognitive reasons to put the brand on the top of their choices, in fact, have key drivers to repurchase the brand. Therefore, one can conclude that brand loyalty results in purchase intent. Based on this result, organizations should first consider customer loyalty to the brand in order to motivate their engagement in social media activities, followed by building loyalty to the brand and repurchase decisions, considering antecedents of social media such as corporate reputation, social media frequency updates, content of social media, social media motivations and brand communications induce three main benefits: enhancing social media marketing, brand loyalty and purchase intention. Social media marketing as measured by application types, social effects and enabling technologies, in turn, will result in improved brand loyalty and purchase intention. Brand loyalty in itself encourages customer purchase intention. A key of this study is related to construct measurement. For example, brand loyalty as a multidimensional construct was measured in this study using two indicators only. Another limitation of the study is that it is a cross-sectional study collected data from customers at one point in time. One of the most important notes is that this study is limited to five antecedents of social media marketing. Therefore, future research should take measurement of such constructs into account to be more sufficient using more indicators and explore the effect of a larger number of antecedents on social media marketing.

\section{References}

Alarcón, M., Rialp, A. and Rialp, J. (2015). The effect of social media adoption on exporting firms' Performance, in Shaoming Zou, Hui Xu, Linda Hui Shi (ed.) Entrepreneurship in International Marketing (Advances in International Marketing, V.25, Emerald Group Publishing Limited, 161-186.

Al-Tit, Ahmad (2016). The Mediating Role of Knowledge Management and the Moderating Part of Organizational Culture between HRM Practices and Organizational Performance. International Business Research, 9(1): 43-54. https://doi.org/10.5539/ibr.v9n1p43

Al-Tit, Ahmad A. \& Nakhleh, Haitham (2014). The Role of E-Marketing in the Development of Internet User Attitudes toward Tourist Sites in Saudi Arabia. Journal of Administrative and Economic Sciences, 7(2): 25-44.

Ashley, C. and Tuten, T. (2015). Creative strategies in social media marketing: An exploratory study of branded social content and consumer engagement. Psychology and Marketing, 32(1), 15-27, https://doi.org/10.1002/mar.20761.

Bajpai, V., Pandey, S. and Shriwas, S. (2012). Social media marketing: Strategy and Impact. International Journal of Social Science \& Interdisciplinary Research, 1(7), 214-223.

Balakrishnan, B., Dahnil, M. and Yi, W. (2014). The impact of social media marketing medium toward purchase intention and brand loyalty among generation Y. Procedia-Social and Behavioral Sciences, 148, 177-185.

Brech, F., Messer, U., Schee, B., Rauschnabel, P. and Ivens, B. (2017). Engaging fans and the community in social media: interaction with institutions of higher education on Facebook. Journal of Marketing for Higher education, 27(1), 112-130.

Brink, T. (2017). B2B SME management of antecedents to the application of social media. Industrial Marketing Management, $64,57-65$.

Bruhn, M., Schoenmueller, V. and Schäfer, D. (2012). Are social media replacing traditional media in terms of brand equity creation? Management Research Review, 35(9), 770-790, https://doi.org/10.1108/01409171211255948.

Byrum, K. (2017). Boosting brand reputation and promoting purchase intention through corporate social responsibility communication: A test of source, formats and sentiment effects in social media. Research Journal of the Institute for Public Relations, 3(2), 1-20.

Calvo-Porral, C., Martínez-Fernández, V., Juanatey-Boga, O. and Lévy-Mangín, J. (2015). Measuring the influence of customerbased store brand equity in the purchase intention. Cuadernos de Gestión, 15(1), 93-118. 
Caruana, A. and Ewing, M. (2010). How corporate reputation, quality, and value influence online loyalty. Journal of Business Research, 63(9/10), 1103-1110, https://doi.org/10.1016/j.jbusres.2009.04.030.

Chen, Y., Chen, T. and Lin, C. (2016). The analyses of purchasing decisions and brand loyalty for smartphone consumers. Open Journal of Social Sciences, 4, 108-116.

Chi, H., Yeh, H. and Yang, Y. (2009). The impact of brand awareness on consumer purchase intention: The mediating effect of perceived quality and brand loyalty. The Journal of International Management Studies, 4, 1, 135-144.

Chinomona, R. (2016). Brand communication, brand image and brand trust as antecedents of brand loyalty in Gauteng Province of South Africa. African Journal of Economic and Management Studies, 7(1), 124139, https://doi.org/10.1108/AJEMS-03-2013-0031.

Constantinides, E. (2014). Foundations of social media marketing. Procedia - Social and Behavioral Sciences, 148, 40-57, https://doi.org/10.1016/j.sbspro.2014.07.016.

Dehghani, M. and Tumer, M. (2015). A research on effectiveness of Facebook advertising on enhancing purchase intention of consumers. Computers in Human Behavior, 49, 597-600, https://doi.org/10.1016/j.chb.2015.03.051.

Dessaert, L. (2017). Social media engagement: A model of antecedents and relational outcomes. Journal of Marketing Management, 33 (5/6), 375-399. https:// doi.org/10.1080/0267257X.2017.

Erdogmus, I. and Cicek, M. (2012). The impact of social media marketing on brand loyalty. Procedia - Social and Behavioral Sciences, 58, 1353-1360.

Gautam, V. and Sharma, V. (2017). The Mediating role of customer relationship on the social media marketing and purchase intention relationship with special reference to luxury fashion brands. Journal of Promotion Management, 1-17, https:/doi.org/10.1080/10496491.2017.1323262

Glynn, M. and Woodside, A. (2009). Business to business brand management: Theory, research and executive case study exercises. Advances in Business Marketing and Business Marketing and Purchasing, 15, Emerald Publishing Limited, UK.

Guede, J., Curiel, J. and Antonovica, A. (2017). Viral communication through social media: analysis of its antecedents. Revista Latina de Comunicación Social, 72, 69-86.

Gul, R. (2014). The Relationship between reputation, customer satisfaction, trust, and loyalty. Journal of Public Administration and Governance, 4, 3, 368-387.

Ha, H., John, J., Janda, S. and Muthaly, S. (2011). The effects of advertising spending on brand loyalty in services. European Journal of Marketing, 45(4), 673-691, https://doi.org/10.1108/03090561111111389.

Hair, J., Black, W., Babin, B. and Anderson, R. (2010). Multivariate data analysis. Pearson, Pearson Education Inc., NJ, USA.

Hajli, N. (2013). A study of the impact of social media on consumers. International Journal of Market Research, 56(3), $387-404$. https://doi.org/10.2501 /U M R -2014-025.

Hayta, A. (2013). A study on the of effects of social media on young consumers' buying behaviors. International Association of Social Science Research-IASSR, Special Issue: Human Resource Management, 65-74.

Hoyle, R. (2000). Confirmatory factor analysis. Handbook of applied multivariate statistics and mathematical modeling, 465497. Academic Press, USA.

Huang, A., Yen, D. and Zhang, X. (2008). Exploring the potential effects of emoticons. Information \& Management, 45, 466-473. https://doi.org/doi:10.1016/j.im.2008.07.001.

Hutter, K., Hautz, J., Dennhardt, S. and Füller, J. (2013). The impact of user interactions in social media on brand awareness and purchase intention: the case of MINI on Facebook. Journal of Product \& Brand Management, 22(5/6), 342351, https://doi.org/10.1108/JPBM-05-2013-0299

Ismail, A. (2017). The influence of perceived social media marketing activities on brand loyalty: The mediation effect of brand and value consciousness. Asia Pacific Journal of Marketing and Logistics, 29(1), 129-144, https://doi.org/10.1108/APJML-10-2015-0154.

Jahn, B. and Kunz, W. (2012). How to transform consumers into fans of your brand. Journal of Service Management, 23(36), 344-361, https:// doi.org/10.1108/09564231211248444.

Keh, H. and Xie, Y. (2008). Corporate reputation and customer behavioral intentions: The roles of trust, identification and commitment. Industrial Marketing Management, 38(7), 732-742, https:/ /doi.org/10.1016/j.indmarman.2008.02.005.

Lafferty, B., Goldsmith, R. and Newell, S. (2002). The dual credibility model: The influence of corporate and endorser credibility on attitudes and purchase intentions. Journal of Marketing Theory and Practice, 10(3), 1-11.

Laroche, M. Habibi, M. and Richard, M. (2013). To be or not to be in social media: How brand loyalty is affected by social media? International Journal of Information Management, 33, 76-82, https:/ / doi.org/10.1016/j.ijinfomgt.2012.07.003

Leung, X., Bai, B. and Mehmet Erdem, M. (2017). Hotel social media marketing: A study on message strategy and its effectiveness. Journal of Hospitality and Tourism Technology, 8(2), 239-255. https://doi.org/10.1108/JHTT-02-20170012.

Liengjindathaworn, S., Saenchaiyathon, K. and Hawat, P. (2014). Effect of corporate reputation to brand loyalty of banks in Thailand. International Business Management, 9(1), 134-138. 
Malik, M., Ghafoor, M. and Iqbal, H. (2013). Importance of brand awareness and brand loyalty in assessing purchase intentions of consumer. International Journal of Business and Social Science, 4(5), 167-171.

Mohammadpour, A., Roshandel Arbatani, T., Hassan Holipour, T., Farzianpour, F. and Hosseini, S.H. (2014). A survey of the effect of social media marketing on online shopping of customers by mediating variables. Journal of Service Science and Management, 7, 368-376. https://dx.doi.org/10.4236/jssm.2014.75034.

Munnukka J., Karjaluoto, H., Mahlamäki, T. and Hokkanen V. (2017). Effects of social media on consumers' sports brand experiences and loyalty. In: Stieler M. (eds) Creating marketing magic and innovative future marketing trends. Developments in Marketing Science: Proceedings of the Academy of Marketing Science. Springer, Cham, https://doi.org/10.1007/978-3-319-45596-9_194.

Muntinga, D., Moorman, M. and Smit, E. (2011). Introducing COBRAs: Exploring motivations for brand-related social media use. International Journal of Advertising, 30(1), 13-46, https:/ / doi.org/10.2501/IJA-30-1-013-046.

Neti, S. (2011). Social media and its role in marketing. International Journal of Enterprise Computing and Business Systems, $1(2), 1-15$

$\mathrm{Ng}$, C. S. (2013). Intention to purchase on social commerce websites across cultures: A cross-regional study. Information \& Management, 50(8), 609-620. https://doi.org/10.1016/j.im.2013.08.002

Odoom, R., Anning-Dorson, T. and Acheampong, G. (2017). Antecedents of social media usage and performance benefits in small- and medium-sized enterprises (SMEs). Journal of Enterprise Information Management, 30(3), 383-399. https://doi.org/10.1108/JEIM-04-2016-0088.

Oztamur, D. and Karakadilar, I. (2014). Exploring the role of social media for SMEs: as a new marketing strategy tool for the firm performance perspective. Procedia - Social and Behavioral Sciences, 150, 511-520, https://doi.org/doi: 10.1016/j.sbspro.2014.09.067.

Pandey, S. and Srivastava, S. (2016). Antecedents of customer purchase intention. IOSR Journal of Business and Management (IOSR-JBM), 18(10), 55-82.

Parganas, P., Anagnostopoulos, C. and Chadwick, S., (2017). Effects of social media interactions on brand associations: A comparative study of soccer fan clubs. International Journal of Sports Marketing and Sponsorship, 18(2), 149165, https://doi.org/10.1108/IJSMS-05-2017-087.

Parveen, F. (2012). Impact of social media usage on organizations. PACIS 2012 Proceedings of 16th Pacific Asia Conference on Information Systems, Ho Chi Minh City, 11-15 July, Paper 192.

Rialti, R., Zollo, L., Pellegrinie, M. and Ciappei, C. (2017). Exploring the antecedents of brand loyalty and electronic word of mouth in social media-based brand communities: Do gender differences matter? Journal of Global Marketing, 30(3), 147-160.

Schivinski, B. and Dąbrowski, D. (2013). The impact of brand communication on brand equity dimensions and on brand purchase intention through Facebook. GUT FME Working Paper Series A. Gdansk (Poland): Gdansk University of Technology, Faculty of Management and Economics, 4(4), 1-24.

Schultz (2017). Proposing to your fans: Which brand post characteristics drive consumer engagement activities on social media brand pages? Electronic Commerce Research and Applications, 26, 23-34.

See-To, E. and Ho, K. (2014). Value co-creation and purchase intention in social network sites: The role of electronic Word-ofMouth and trust - A theoretical analysis. Computers in Human Behavior, 31, 182-189, https://doi.org/10.1016/j.chb.2013.10.013.

Seo, E. and Park, J. (2017). A study on the impact of airline corporate reputation on brand loyalty. International Business Research, 10(1), 5967.

Shahid, Z., Hussain, T. and aZafar, F. (2017). The impact of brand awareness on the consumers' purchase intention. Journal of Marketing and Consumer Research, 33, 34-38.

Sharif, M., Troshani, I. and Davidson, R. (2015). Public sector adoption of social media. Journal of Computer Information Systems, 55(4), 53-61.

Sheth, S. and Kim, J. (2017). Social media marketing: The effect of information sharing, entertainment, emotional connection and peer pressure on the attitude and purchase intentions. GSTF Journal on Business Review (GBR), 5(1), 62-70.

Singh, T. and RatnaSinha (2017). The impact of social media on business growth and performance in India. International Journal of Research in Management \& Business Studies, 4(1), 36-40.

Tatar, Ş and Eren-Erdoğmuş, İ. (2016). The effect of social media marketing on brand trust and brand loyalty for hotels. Information Technology and Tourism, 16(3), 249-263, https://doi.org/10.1007/s40558-015-0048-6.

Thoene, W. (2012). The impact of social networking Sites on college students' consumption patterns. Huntington, West Virginia: Thesis for Master's in Marshall University.

Tuten, T. L., \& Solomon M. R. (2015). Social Media Marketing. California: Sage Publications Ltd.

VanVoorhis, C. and Morgan, B. (2007). Understanding power and rules of thumb for determining sample sizes. Tutorials in Quantitative Methods for Psychology, 23 (2), 43-50.

Vinerean, S., Cetina, I. and Tichindelean, M. (2013). The effects of social media marketing on online consumer behavior. International Journal of Business \& Management, 8(14), 66-9. https://doi.org/10.5539/ijbm.v8n14p66. 
Wonly, J. and Mueller, C. (2013). Analysis of fashion consumers' motives to engage in electronic word-of-mouth communication through social media platforms. Journal of Marketing Management, 29 (5/6), 562-583.

$\mathrm{Wu}, \mathrm{W}$. and Anridho, N. (2016). The antecedents of brand loyalty: a meta-analysis study. International Journal of Services and Standards, 11(3), 242-260.

Yadav, M. and Rahman, Z. (2017). Measuring consumer perception of social media marketing activities in e-commerce industry: Scale development and validation. Telematics and Informatics, 34(7), 1294-1307, https://doi.org/10.1016/j.tele.2017.06.001.

Zahoor, S. and Qureshi, I. (2017). Social media marketing and brand equity: A literature review. IUP Journal of Marketing Management, 16(1), 47-64. 